Original Article (short paper)

\title{
Teaching handball to U-16 and U-18 women's teams: coaches' perspective on the long-term
}

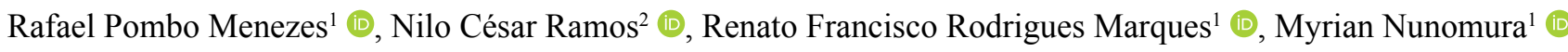 \\ ${ }^{1}$ Universidade de São Paulo, USP, School of Physical Education and Sport of Ribeirao Preto, \\ Ribeirão Preto, SP, Brazil; ${ }^{2}$ Coastal Carolina University, College of Education, Myrtle Beach, SC
}

\begin{abstract}
Aims: To identify the teaching approaches preferred by Brazilian coaches in the U-16 and U-18 women's teams and whether it is possible to apply long-term goals for handball training. Methods: Six experienced coaches were interviewed individually in a semi-structured format. Data were transcribed and analyzed according to the Collective Subject Discourse (CSD) method. Results: Coaches revealed a choice for the situational approach and global-functional approach in U-16 teams. In U-18 teams, coaches' choices were for the technique and situational approaches. The change of coaches' choice might be based on players' specialization, suggested to U-18 teams when coaches highlighted the increased demand for performance. On players' transition from U-16 to U-18 teams, the coaches showed less preference for the global-functional approach and increasing evidence of the technique approach. Conclusion: Global-functional and situational approaches should be given a prominent position in these teams, especially due to the development of technical-tactical aspects. However, the technical approach was recognized as a central position in U-18 teams, probably related to players' specialization and technical improvement, although it does not offer a rich environment for the development of players' decision making.
\end{abstract}

Keywords: team sports; sports coaching; youth sports; sports pedagogy; handball.

\section{Introduction}

The complex context of handball is determined by simultaneous and unpredictable relations of cooperation and opposition among players, which requires tactical behaviors adjusted to the game demands ${ }^{1}$. This context has also required a paradigm shift in teaching team sports, prioritizing a player-centered approach rather than a teacher-centered approach ${ }^{2,3}$.

In this context, players must be encouraged to develop problem-solving skills and critical thinking ${ }^{2}$ in long-term training ${ }^{3}$. Abilities such as perception, attention, anticipation, and decision-making are crucial to team sports ${ }^{4}$, which can be stimulated and developed in different ways. This demands that coaches possess the knowledge of teaching approaches and technical and technical-tactical content.

Considering players' experiences, their development occurs in different stages, from their initiation in handball (around 12 years old, in a diversified environment with the promotion of free and creative play) until reaching adult teams, with a high level of specialization. In each stage, coaches should consider specific goals based on players' characteristics such as previous experiences, levels of maturation, growth, and development ${ }^{5}$.

Identifying the aspects of handball teaching at each sport-specific development age (under-12, under-14, under-16 and under-18 teams) could provide parameters to handball coaches who participate in sport-development processes of young players, especially in the Brazilian context.
Thus, the aim of this study was to investigate Brazilian handball coaches' perspectives on the main pedagogical approaches to teach handball to under-16 (U-16), and under-18 (U-18) teams. Specifically, the goals of this study were to a) identify the approaches used by coaches in the state of São Paulo (specific Brazilian context) and b) discuss the coaches' reasons for adopting their pedagogical approaches in both teams (U-16 and U-18) and a possible long-term teaching choice.

The investigation of coaches' perspectives in these teams allows the comparison with other development-age stages (e.g., U-12 and U-14) ${ }^{6,7}$, unveiling the procedures used in a long-term pedagogical process. Therefore, the intent is to reveal the pedagogical goals and procedures adopted by coaches in training sessions of U-16 and U-18 handball teams, which are the decisive stages in sports development ${ }^{8}$, especially in handball ${ }^{9}$. To reach this goal, the discourses of Brazilian handball coaches were collected and discussed using semi-structured interviews.

This article begins with a theoretical framework when we present some more commons teaching approaches of team sports in the Brazilian context. In the next session, we present the methodological decisions. Next, we present the findings and discuss the perspective of interviewed coaches (of the São Paulo state) about their pedagogical approaches preferred to teach handball to U-16 and U-18 teams.

After presenting this background, two relevant questions are pertinent: 1) "are there any differences between coaches' preferred teaching approaches for U-16 and U-18 teams?"; 2) "when comparing with other studies, is it possible to identify long-term teaching choices?". 


\section{Theoretical Framework}

Studies related to team sports teaching approaches - whether through the technique approach, teaching through games or games situations - have been important to understand the development of Brazilian children and youth in sports ${ }^{6,10-12}$. In our study, teaching through games (global-functional approach) ${ }^{13}$ and teaching through games situations (situational approach) $)^{14,15}$ are the theoretical framework in which the coaches' statements are discussed.

Team sports have been taught traditionally based on the technique approach ${ }^{3,16,17}$. This approach prioritizes the skills development without relations to the game context ${ }^{3}$, without considering the complexity of the game environment ${ }^{18}$. Other criticisms for this approach include the players do not feel motivated with the exercises ${ }^{3}$ and the poor transfer of learned skills to the game ${ }^{16}$. In this approach, it is believed that the player must "learn to play".

For this historically established paradigm, especially in Brazil $^{3,15}$, some approaches which prioritize the understanding of the game gained notoriety, such as global-functional and situational approaches. These approaches are based on game understanding, in an opposite way when compared to the technical approach, as an alternative to the trend ${ }^{23,19,20}$. There are common aspects between global-functional and situational approaches, including the emphasis in the comprehension of tactical aspects of the game and the fact that it is not restricted to complete mastery and automation of skills, which highlights the complexity of decision making ${ }^{3,13,15}$.

The global-functional approach prioritizes the concomitant development of the capacity to solve cognitive and motor tasks in a game context ${ }^{15}$. This approach involves the use of games of increasing complexity, including technical, tactical and regulatory aspects ${ }^{21}$. In this approach, it is believed that the player must "play to learn". Additionally, this approach is based on the player's understanding of the game dynamics, as a way to develop the players' ability, which can be transferred to other sports ${ }^{21}$. For this, adaptations to game rules allow players to access the proposed contents ${ }^{22}$, from the adjustment of difficulty levels according to the characteristics of the players ${ }^{3,23}$ to coaches' goals and objectives on possible game situations.

The importance of players' decision making is justified by the complex context of team sports, which is directly influenced by the interactions with teammates and opponents ${ }^{19}$. This context justifies the gradual change of game rules, as players start to make simple decisions, and provide the development of the technical and tactical aspects concomitantly.

In the situational approach ${ }^{24}$, the interrelation between the technical and tactical aspects to solve the specific problems of the game is a core principle. This approach is based on formal game situations, developed in a less complex context (such as $1 \times 1,2 \times 1,3 \times 2$, etc.), while maintaining the objectives, principles, and elements of the formal game ${ }^{23}$. Although different solutions are accepted for the same problem situation ${ }^{12}$, this method emphasizes that the decision made will imply changes in the game scenario ${ }^{3}$. For Ricci, Reis, Menezes, Dechechi,
Ferreira ${ }^{12}$ situational approach is relevant for the development of players' tactical thinking and to understand the reasons for their interventions.

These two approaches (global-functional and situational) are concerned in a players-centered way, through the situations presented by games or games specific situations. In this way, the importance of "play to learn" is emphasized, opposing the premise that it is necessary to "learn to play" (as prioritized by the technical approach ${ }^{25}$. In this sense, these approaches prioritize player development in complex contexts, which emphasize the relations of cooperation and opposition and, consequently, a better understanding of the game (when compared to the technique approach).

Previous studies involving Brazilian coaches have analyzed the teaching of handball in U-12 and U-14 teams from Brazilian coaches' perspective. In U-12 teams, coaches showed a preference for teaching through games, justified by the complex environment in which game skills can be developed. Coaches also indicated less preference for the technique approach ${ }^{7}$.

In U-14 teams, coaches also preferred the teaching through games and the technical approach ${ }^{6}$, but it was observed an increase in coaches' choices for situational and technical approaches in U-14 teams (when compared to U-12 teams). The differences between U-12 and U-14 teams might be explained by the specific rules of the competitions, players' characteristics and the increase in sport-specific specialization.

\section{Methods}

\section{Research Design}

A qualitative research design was adopted to access information of a descriptive nature ${ }^{26}$ from coaches' perspectives related to teaching approaches in U-16 and U-18 teams. Qualitative research is widely applied to understand the nature of a social phenomenon, as a way to deeply understand the meanings of the interview content ${ }^{27}$. Semi-structured interviews were conducted ${ }^{26}$ to gain information regarding coaches' choices of the possible pedagogical procedures in U-16 and U-18 handball teams.

\section{Participants and Ethical Aspects}

A purposeful sampling ${ }^{28}$ was used to select coaches of women's teams in the state of São Paulo, Brazil. The criteria to participate in the study were: a) be currently coaching an adult women's handball team; b) be part of the top-three coaches group of the "Jogos Abertos do Interior" of the state of São Paulo (when this study was conducted) with adult women's teams ( $1^{\text {st }}$ and $2^{\text {nd }}$ divisions); and c) have acted as a head coach or assistant coach on youth teams comprising all age ranges (from U-12 to adult teams).

The rationale for the choice of São Paulo state is due to its outstanding position in the Brazilian women's handball context ${ }^{29}$. Among the 21 editions of the women's Handball Adult National 
League, teams from São Paulo state have reached first place in 15 editions and runner-up in nine.

Six coaches who qualified for this study were contacted by phone or email to explain and verify their availability to participate. All contacted coaches agreed to participate in the study (C1, C2, C3, C4, C5, C6), and signed the Informed Consent Form previously approved by the Institutional Research Ethics Committee (CAAE: 18016013.0.0000.5407), to ensure the confidentiality of personal information and the exclusive use of discourses only for academic purposes. All coaches have an undergraduate degree in Physical Education, and their characteristics are presented in Table 1.

In addition to coaching adult teams on the interviews' date, the coaches also have had coached $(n=6)$ or were still coaching $(n=4)$ teams from U-16 and U-18, with an average time of coaching of $6.0( \pm 2.8)$ and $7.5( \pm 4.6)$ years, respectively (Table 1).

Table 1. Coaches characteristics

\begin{tabular}{cccccc}
\hline Coach & Age & $\begin{array}{c}\text { Experience as Physical } \\
\text { Education Teacher (year) }\end{array}$ & $\begin{array}{c}\text { Experience as } \\
\text { coach (years) }\end{array}$ & $\begin{array}{c}\text { Experience in U-16 } \\
\text { teams (years) }\end{array}$ & $\begin{array}{c}\text { Experience in U-18 } \\
\text { teams (years) }\end{array}$ \\
\hline $\mathrm{C} 1$ & 49 & 28 & 28 & 7 & 7 \\
$\mathrm{C} 2$ & 48 & 28 & 13 & 3 & 3 \\
$\mathrm{C} 3^{*}$ & 42 & 19 & 20 & 10 & 15 \\
$\mathrm{C} 4^{*}$ & 31 & 10 & 13 & 3 & 4 \\
$\mathrm{C} 5^{*}$ & 42 & 8 & 14 & 5 & 5 \\
$\mathrm{C} 6^{*}$ & 44 & 15 & 20 & 8 & 11 \\
Mean \pm sd & $42,7 \pm 6,4$ & $18,0 \pm 8,6$ & $18,0 \pm 5,9$ & $6,0 \pm 2,8$ & $7,5 \pm 4,6$ \\
\hline
\end{tabular}

*Currently coaching U-16 and U-18 teams

\section{Interview procedures and discourse analysis}

Semi-structured interviews with coaches were done by one researcher and took four months due to their availability in the regular season. Interviews lasted an average of 1 hour and 16 minutes (total time of 7 hours and 36 minutes). The time spent with the coaches allowed a deep understanding of the pedagogical procedures adopted in the U-16 and U-18 teams, opening up different prerogatives for the analysis and interpretation of their discourses.

Although the semi-structured interview has an initial script (which may be followed chronologically or not, but guarantees the intended content), coaches were able to broadly express their views on the teaching process of the U-16 and U-18 teams ${ }^{26}$. The semi-structured interview was chosen to allow the trainer to discuss the central theme of this study, allowing better access to subjective data ${ }^{30}$.

The interviews with participants were scheduled at different times and places indicated by coaches to avoid conflict with their daily routines. The semi-structured interviews were applied to access coaches' discourses ${ }^{26}$ starting from the following questions: 1) "How do you teach handball for U-16 team?"; 2) "How do you teach handball for U-18 team?". It was possible to identify the approaches used by the coaches in both teams (U-16 and U-18), to understand the dynamic processes experienced by this group and the particularities of coaches' perspectives ${ }^{27}$. Coaches' statements were individually digitally/tape recorded and transcribed verbatim to increase accuracy ${ }^{31}$. In order to validate the statements and evidence of participants' discourses, the transcription of interviews was sent by email to the subjects for checking ${ }^{7}$.
Two researchers (in the Sports Pedagogy field, with vast experience in teaching team sports) tabulated and analyzed the discourses, which were analyzed based on Collective Subject Discourse (CSD) method ${ }^{32}$. The CSD method ${ }^{32,33}$ preserves the discursive nature of opinions, considering that people within a group cannot share similar ideas ${ }^{32}$, which provides the elaboration of how many discourses are needed. In this method, starting from an inductive base, similar ideas can be identified and aggregated through open questions, in which each CSD presents and articulates the different arguments of a certain opinion ${ }^{32}$.

The CSD method consists of three methodological figures: key expressions (continuous or interrupted excerpts that reveal the essence of discourse), central ideas (reveals and synthesizes the meaning of each set of key expressions), and the CSD (combination in a synthesis-discourse of the key expressions with the same central idea; and expresses the collective reference of the discourse $)^{32,33}$. Thus, coaches' thought categories are revealed, allowing the identification and reconstruction of similar ideas from the set of individual discourses.

\section{Discussion}

Coaches' discourses revealed the teaching approaches preferred in U-16 and U-18 teams. Three CSD were identified for U-16 teams: CSD1- technique approach (shared by three coaches), CSD2- situational approach (shared by all coaches); CSD3- global-functional approach (shared by five coaches). When asked about U-18 teams, three CSD were developed: CSD4- technique approach (shared by all coaches), 
CSD5- situational approach (shared by five coaches), and CSD6- global-functional approach (shared by two coaches). In the CSD7, coaches justified some performance differences between U-16 and U-18 teams (Table 4).

It was possible to identify that all coaches use at least two different pedagogical approaches in U-16 teams, suggesting the variability of stimulus in the training sessions. In U-18 teams, five coaches presented choices for at least two approaches and one coach presented a choice for only one (technique approach).

The following differences between the CSD of U-16 (Table 2) and U-18 teams (Table 3) were identified: 1) the increase of the choice for the technical approach in U-18 teams; 2) the reversal of preferred teaching approaches (U-16: situational vs U-18: technique); 3) the balanced choice for both approaches (situational and technique) in U-18 teams; 4) the decrease in global-functional approach in U-18 teams.

Considering the CSD1 (Table 2), coaches pointed out to performing various exercises without opposition, which does not occur in the formal game. Coaches try to motivate players during training sessions but they recognized that these sessions can be boring and monotone. Thus, different stimuli were provided by them, mainly related to balls of different weight and to exercise load.

Table 2. CSD of U-16 teams

\section{CI-1: Technique approach (C1,C2,C5)}

CSD1: The tendency to have a more technique situation, with more isolated technical exercises ${ }^{\mathrm{Cl}, \mathrm{C} 2, \mathrm{C} 5}, 50 \%$ technique ${ }^{\mathrm{Cl}}$. We will practice a bit isolated for a short time, otherwise the player becomes disinterested ${ }^{\mathrm{C} 5}$; if it is throwing, then let's go, only throwing ${ }^{\mathrm{Cl}}$. It is not that monotonous thing, but it is with a lot of encouragement: bungee cord, bed sheet on the elastic cord to block the goalkeeper's view, mini-volleyball net, goal post inside the court for the wing's throws, tennis balls ${ }^{\mathrm{Cl}}$. All you can give as stimulus of light, heavy, larger, smaller, lighter, height, jumps the bench then receives the ball and throws, receives a charge, gives a little push, loses balance, jumps and throws ${ }^{\mathrm{Cl}}$.

\section{CI-2: Situational approach (all coaches)}

CSD2: I will not quit using the situational [when compare to U-14], but it will decrease ${ }^{\mathrm{C} 1}$. In the U-16 I think it begins to have a little more game situations ${ }^{\mathrm{C} 2}$, I already start placing blocks ${ }^{\mathrm{C} 3}$, I cut out the game and I get in that situation where I need to make a pass and I cut out of the game and put it there in practice ${ }^{\mathrm{C} 4}$. You can work the relationship between offense and defense $\mathrm{C}^{\mathrm{C} 5}$ in depth $^{\mathrm{C} 2}$, do some work $1 \times 1$, $2 \times 2$, to start in this progression, and start doing $3 \times 3^{\mathrm{C} 2, \mathrm{C} 3, \mathrm{C} 5, \mathrm{C} 6}, 4 \times 4^{\mathrm{C} 3, \mathrm{C} 4, \mathrm{C} 5}$. I always tell the athletes: "I'm giving you the options, I do not know what will be happening in the game" $\mathrm{C4}$.

\section{CI-3: Teaching through games $(\mathrm{C} 1, \mathrm{C2}, \mathrm{C} 3, \mathrm{C} 4, \mathrm{C} 6)$}

CSD3: In the U-16 it should already start making these games of "keep away", in which I have to move and know that the other is also moving ${ }^{\mathrm{C} 3}$. In the game I work with the distance of the pass [short, medium, long]; the passes at this moment may be varied ${ }^{\mathrm{C} 2}$. The game enriches enough when you see that some players still have difficulty; the game is a tool for you to teach these players who have difficulty in the execution of specific movements; not everyone will get the same reading and that player who is still not being able to understand the situations will have the opportunity ${ }^{\mathrm{C} 2}$.

Continues to enter the pre-sport, but not as the protagonist, I will not quit using games, but I will decrease it ${ }^{\mathrm{Cl}, \mathrm{C} 2, \mathrm{C} 6}$, but I keep it because the kids like it ${ }^{\mathrm{C} 6}$. The playful serves only for warming-up at times, which will be part of the preparation for practice ${ }^{\mathrm{C} 4, \mathrm{C} 6}$.

Table 3. CSD of U-18 teams

CI-4: Technique approach (all coaches)

CSD4: You have to improve technique to the fullest, working especifically ${ }^{\mathrm{C} 4, \mathrm{C} 5, \mathrm{C} 6}$, with a lot of repetition for the player better understand what is being said ${ }^{\mathrm{C}}$. It is the age that you can get the most out of the player in relation to technique, because he already has good knowledge ${ }^{\mathrm{C} 6}$; this technique is specific on offense and defense ${ }^{\mathrm{Cl}}$. There is a sequence of passing exercises, all of the players shifting: shoulder pass, jump pass, rolling pass ${ }^{\mathrm{C} 2 \mathrm{C} 3}$. In the U-18 we can have longer passes, I didn't do long passes in the U-16 or U-14 because the margin of error is still too large ${ }^{\mathrm{C} 3}$. There is practice that you will start with the technique as a warm-up ${ }^{\mathrm{C} 2}$, like face to face, making passes ${ }^{\mathrm{C} 3}$; there are exercises used for warm-up, to warm-up the goalkeeper, shots from the positions ${ }^{\mathrm{Cl}}$. I say that the warm-up should not be face to face, but we do it to warm-up the joints ${ }^{\mathrm{C} 3}$.

\section{CI-5: Situational approach $(\mathrm{C} 1, \mathrm{C} 2, \mathrm{C} 4, \mathrm{C} 5, \mathrm{C} 6)$}

CSD5: Everything is a cutout of the game, show the options; It starts working the answers in the U-16 and in U-18 improve them. The player needs to understand that what she's thought to do can change and she has to make decision ${ }^{\mathrm{C}}$. These situations will always make me work passing, throw, dribble; is embedded in this action the throw and the pass with pressure, always with game stimulus ${ }^{\mathrm{Cl}}$. Work specific game simulation $^{\mathrm{C5}}$ and maintain smaller situations ${ }^{\mathrm{Cl}, \mathrm{C} 2, \mathrm{C} 4, \mathrm{C} 6}$, using numerical superiority and inferiority ${ }^{\mathrm{C} 6}$ such as $4 \times 3$, $3 \times 2$ and the $5 \times 4^{\mathrm{Cl}}$, but begins to create more difficulty for the players ${ }^{\mathrm{C} 4}$. I also use a lot of transition, ball recovery, with $2 \times 1$ on the entire court, $3 \times 2$ on the entire court, in sectors $^{\mathrm{Cl}}$. You have to make she understand that she is playing with ball, without the ball, with the ball close, with the ball away, and he has to position him/herself in respect to it ${ }^{\mathrm{C} 4}$.

\section{CI-6: Teaching through games (C2,C4)}

CSD6: In the U-18 I think there are sessions in which you can use small games that serve as warm-up ${ }^{\mathrm{C} 2 \mathrm{C} 4}$. Games are just for play, it is just to warm-up sometimes ${ }^{\mathrm{C} 4}$. Games in U-18 as warm-up do not necessarily a handball game, I can give them another sport, there's a lot of wealth of information ${ }^{\mathrm{C} 2}$. There is a game that I give them where the goalie is there, she will be scored on from outside [the court] which is handball while at the same time playing soccer ${ }^{\mathrm{C} 2}$ [in the internal space of the court, similar to the dynamics of hockey]. 
CSD1 indicates a choice for the technical approach in U-16 teams. This proposal focuses on learning skills disconnected from tactical problems, focusing on repetition of specific movements of handball. It is believed that learning technical skills is necessary to learn game skills. However, it can have characteristics such as the non-transfer of learned elements for the game context due to teaching "how to do" from exhaustive repetition that is disconnected from the reasons, or the "why", "when" and "where", which can be boring to the players ${ }^{3,15}$.

On the other hand, coaches were unanimous in CSD2 (Table 2) when described the choice for teaching handball based on game situations, addressing the progression of game situations from $1 \times 1$ to $4 \times 4$. Coaches believe that in U-16 teams the game situations need to be more frequent in training sessions, when compared to U-14 teams, justified by the central importance given to formal play. They also highlight that players are encouraged to solve unpredictable situations of the game, specially provided by relationships between teammates and opponents, in a similar context described in U-14 teams when TGfU were mentioned by handball coaches ${ }^{7}$.

It is important to highlight the concern of authors such as Ehret, Späte, Schubert, Roth ${ }^{34}$ and Greco, Silva, Greco ${ }^{35}$ for the contextualization of individual tactics during group (team) actions in the U-16 teams, which allows different development in numerical relationships of $3 \times 3$ and $4 \times 4$. In this sense, Greco and Benda ${ }^{36}$ discussed that working on game situations involving smaller groups of players is more effective, where players can play more actively, have more contact with the ball, and interact more in smaller groups. Nevertheless, Ehret, Späte, Schubert, Roth $^{34}$ also suggested the beginning of specialization of positions, however, that players act in all positions, with attention to the development of individual tactical aspects in each specific court position.

In CSD3 (Table 2), coaches pointed out the choice to use games as a pedagogical strategy (CSD3) to level the knowledge of game dynamics, and thus, to allow players to understand the game as a whole rather than as a sum of its parts (technique approach). CSD3 also mentioned the main feature of global-functional approach, whose emphasis is centered on the resolution of problem-situations, which requires the application of technique repertoire in the game context. Therefore, the concern is with the effectiveness of the actions rather than their efficiency.

Under this view, it is emphasized that teams are composed by players with different experiences, and some players start to play handball in U-16 teams, which increases the complexity of the relationships between these players (experienced vs. novices). The unpredictable contexts provided by games have the premise of improving the repertoire of the motor and cognitive solutions, which are essential to decision-making.

Ricci, Reis, Menezes, Dechechi, Ferreira ${ }^{12}$ evaluated the learning of young handball players in the situational approach and cited that these players presented a greater number and more consistent application of tactical solutions. Both approaches cited in CSD2 and CSD3 are based on the development of gaming competencies from problem-situations that involve the presence of opponents in complex and dynamic contexts, which retain offensive (keep ball possession, progress towards the opponent's target and finish on target) and defensive (regain possession of the ball, prevent opponent's progression and protect your target) principles ${ }^{37,38}$.

The findings with U-16 teams support Greco ${ }^{15}$ and Menezes, Marques, Nunomura ${ }^{3}$ that cited these characteristics in the globalfunctional and situational approaches, which aim to develop players' abilities in environments with game dynamics and interactions between players. Supporting the indications made by these authors, Costa, Garganta, Greco, Mesquita, Muller ${ }^{39}$ pointed out that deficiency in the tactical domain may compromise the use of technical skills. Therefore, we understand that once the U-16 team is reached, the TLP should focus on the development of elements and tactical skills that will allow technical improvement in following stages.

The concern with the development of gaming skills is a theme treated as a key element in this stage of the long-term training in handball ${ }^{34,35}$, which is related to the comprehension of tactical aspects and the ability to make contextualized decisions. Similarly, Greco, Silva, Greco ${ }^{35}$ presented that in U-16 teams the development of tactical intelligence from different games should be prioritized. This concern was also demonstrated by coaches in both discourses that emphasized situational approach drawn from formal game situations (as mentioned in CSD2) and through games (CSD3).

The coaches' positions in the U-18 teams revealed a choice for the technical approach (CSD4) and for situational principles (CSD5). CSD4 (Table 3) expresses the opinion of all coaches, emphasizing the technical approach for U-18 teams, which was justified: a) as a warm-up activity for players without opposition, whose focuses on the technical execution outside the game context; and b) by prioritizing the technical improvement of players in their specific positions. In regards to this second aspect, the coaches mentioned the specific technical development of offensive and defensive skills separately, as well as the sequences of passing and throwing exercises (without opposition).

Nevertheless, coaches use the technical approach to improve technical aspects (as passes, throws, dribbling) based on many repetitions. Therefore, it is possible to emphasize long passes (CSD4) due to the better precision when compared to U-14 and U-16 teams. For Ehret, Späte, Schubert, Roth ${ }^{34}$ long-term handball training should be supported by game activities in training sessions that allow players to adapt to different offensive and defensive contexts, including U-18 teams. In contrast, the authors indicated that technical aspects, such as passing and throwing variations, should also be emphasized out of the game context. In CSD4, it was possible to identify the coaches' choice for the technical approach, justified by the need for improving technical aspects and specialization of players, which partially agrees with the premises mentioned by Ehret, Späte, Schubert, Roth ${ }^{34}$.

Greco, Silva, Greco ${ }^{35}$ reported that in the U-18 teams there is more emphasis on the quality and variation of actions such as feints, especially before a tactical action. However, the authors indicated the importance of the development of individual and collective game against different defensive scenarios (as pointed 
out by Ehret, Späte, Schubert, Roth ${ }^{34}$ ), which is not emphasized by the technique approach, as shown in CSD4. Conversely, we found some contradictory ideas in the last phrase of CSD4, when presented that 'the warm-up should not be face to face', but does it to warm-up the joints. Although the coach knows that it may not be the most appropriate option (for not having opposition and not contemplating any requirement of the game), this continues to be done that way.

As shown in the discussion of the results of the U-16 teams, the technique approach aimed for the technical improvement by the repetitions of this element searching for efficiency. In our study, the coaches demonstrated an increased choice for using the technique approach in U-18 teams when compared to U-16. This highlights the important characteristic of developing some specific technical requirements in the specialization of players. Focusing on the disadvantages of the technique approach, we understand that it does not stimulate the players because it does not consider the complexity of the formal game. Considering that the main reason for the coaches to use this approach is to improve specific skills, we understand that this also can be done in real game situations, with a reduced number of players and without opposition (as $1 \times 0,2 \times 1,2 \times 0 \ldots$ ).

In contrast to the technique approach, coaches reported in the CSD5 (Table 3) that the situational approach provides similar stimuli to technical and tactical requirements of handball game in U-18 teams, especially those related to the relationships between teammates and opponents. CSD5 expresses the high complexity of the decision-making ability required by game situations in U-18 teams, and these should have progressive difficulties.

The situational approach should maintain the structure of the handball game ${ }^{3,12,15}$, being more suitable for the teaching of handball when compared to the technique approach. It is presented (CSD5) the possibility of using this approach in the transition phase (defense to offense), when it is suggested the practice of offensive numerical superiority as a way to enable a fast counterattack after regaining ball possession.

Ehret, Späte, Schubert, Roth ${ }^{34}$ indicated that in U-18 teams there must be positional training, in which players act in various positions. Similarly, Greco, Silva, Greco ${ }^{35}$ recommend that players operate in different positions, both on offense and on defense, without specialization, further suggesting the development of individual and group play in different defensive systems. This assumption is justified by the development of playing ability in different specific court positions in offensive and defensive contexts (Ehret, Späte, Schubert, Roth ${ }^{34}$ ).

In contradiction, we highlight the CSD6 (Table 3), which demonstrated the low importance given to global-functional approach by coaches in U-18 teams. Coaches suggested that there is an understanding that games might be used only for fun in warm-up activities, disregarding the situations that resemble the demands of the formal game such as the relations of cooperation and opposition, game principles, and the requirements of the complex context for the players' decision-making.

We emphasize that game creates an unpredictable environment, in which changes may occur according to the technical and tactical behavior of players. However, the game cannot be understood in a technocratic way, as proposed by the technique approach ${ }^{15}$.

Games can be used, therefore, to teach main specific contents of handball, especially by the maintenance of complex characteristics of the game context ${ }^{3}$. It is also justified as an active teaching approach to tactical development and construction of knowledge guided by the diversity of stimuli ${ }^{3}$. Games also attend players' desire to play and allow the approximation to problem-situations of tactical order when rules are modified, but it is difficult to change the coaches' mentality to teaching through games ${ }^{40}$.

Antón García ${ }^{41}$ recommended that U-16 teams fit the acquired technique in specific court positions, suggesting the beginning of this kind of specialization. Ehret, Späte, Schubert, Roth ${ }^{34}$ pointed out that U-16 players should have access to situations that provide multiple possibilities of group actions, which would be relevant from the use of global-functional and the situational approach, in which the tactical requirements are similar to the demands presented in the formal game. Both approaches seem to be appropriate, with spatial variations and numerical relationships between teammates and opponents.

Ehret, Späte, Schubert, Roth ${ }^{34}$ and Greco, Silva, Greco ${ }^{35}$ addressed the specification of court position in U-16 teams, signaling a possible beginning of player specialization. For them, players need to be encouraged to play in all positions, allowing contact with different aspects related to each sector of the court. Thus, the aforementioned authors understood that in the U-16 teams players must have varied experiences that allow the development of different technical and tactical offensive and defensive abilities, in addition to expanding the repertoire of actions and resolutions of problem-situations. We observe that the development of these skills might be reached with different stimulus provided by the choice of teaching approaches.

Therefore, teaching approaches in U-16 and U-18 teams must be based on pedagogical principles that allow players to understand the game and its possibilities of action in specific court positions. The use of different approaches in U-16 and U-18 teams need to be considered to enable a gradual increase of game complexity as presented in U-12 $2^{7}$ and U-14 handball teams ${ }^{6}$.

CSD7 (Table 4) pointed that physical fitness becomes more intense in U-18, which supports Antón García ${ }^{41}$, for whom the development of physical capacities should be done simultaneously to motor skills, but independent from the technical and tactical training:

Coaches also indicated in CSD7 the increase of performance demands in U-18 teams, with higher pressure for results when compared with U-16 teams (when approximately $25 \%$ of the total time is spent with physical fitness), and with players' efficacy as an indicator to competitive situations (CSD7). These findings address more time spent on physical fitness, developed within the $50 \%$ of the time dedicated for technical training, suggesting the beginning of specialization of players according to court positions ${ }^{34,41}$.

Based on our findings and comparing with Menezes, Marques and Nunomura ${ }^{6,7}$, it was possible to observe that in long-term handball training the interest of coaches by teaching through 
games decreases from U-12 to U-18 teams (when reaches the lowest level). In contrast, from U-14 to U-18 teams the interest in the technical approach increases, reaching the highest level in U-18 teams. A similar scenario was observed with the situational approach when the highest choice was in U-16 teams.

These assumptions point to a trend towards the teaching context in which player specialization is achieved/consolidated in U-18. This specialization is prioritized by increased choice for situational and technique approaches. Another aspect that may influence the preferred teaching approaches in U-12 and U-14 teams is the restrictions imposed by competition rules, which were not analyzed in this study. Thus, coaches' discourses have revealed that the technical approach is important for a player's specialization, which is preferably used after learning the game (provided by other approaches).

Still, when considering long-term handball training, it was observed that the global-functional approach is less preferred and was strongly related to the playful character, as compared to the tactical dimension. Menezes, Marques and Nunomura ${ }^{7}$ revealed that coaches of $U-12$ teams believe that games must be a central element of teaching, as they enable the development of different aspects that support the decision making in handball.

Table 4. Differences in performance between U-16 and U-18 teams

\section{CI-7: Increase of performance demands $(\mathrm{C} 1, \mathrm{C} 4, \mathrm{C} 5, \mathrm{C6})$}

CSD7: U-18, actually, my U-16 starts to do physical work, then this 50-50 I talk about [50\% technique and 50\% global and situational], has a little part of these $50 \%$ of technique that the players are going through the gym $3 \mathrm{x}$ a week, are already doing something on the track, push$\mathrm{ups}^{\mathrm{Cl}}$. The main part of the practice is serious, demanding performance ${ }^{\mathrm{C} 4}$; my practice is an hour and a half where you come out soaked [with a lot of sweat], without wasting time ${ }^{\mathrm{Cl}}$. In the U-18 becomes clearer that performance counts a lot, the player has to be aware that if he made 10 passes and missed 8 he will not start playing and will be a while before getting in ${ }^{\mathrm{C} 4}$. U-18 he's starting to understand the competition, then the coach has to guide so they have better direction, which will make this player understand that is important to become a great player; it is at this time that he chooses whether to play or not, if he will work or study ${ }^{\mathrm{C} 5}$. I think that it starts to direct the player's positions ${ }^{\mathrm{C} 6}$, starting to make a little of specific work, because it is almost practically defined the position of each one of them ${ }^{\mathrm{C} 6}$.

We understand, therefore, that mutual use of the methods mentioned by coaches can promote the development of handball players in the long term, enabling them to make decisions according to the context presented by teammates and opponents. On the other hand, the contribution of the technical approach for learning the handball game is not clear, as well as for the players' development.

Coaches should be concerned about increasing the players' decision-making repertoire as they approach the U-18 team. This perspective would allow players more knowledge about the game and its possibilities of interaction with teammates and opponents. For this, it would be necessary to prioritize the situational and global-functional approaches. A curriculum for handball teaching can consider the aspects presented herein since relevant content can be emphasized based on the arguments of experienced coaches. In this sense, one of the factors that might be considered in this curriculum is the increase of performance requirements in the long-term handball training.

\section{Conclusion}

This study analyzed the discourses of Brazilian handball coaches (from the state of São Paulo) and identified the preferred teaching approaches in U-16 and U-18 teams. Although coaches adopted similar approaches in both teams, there was a balance between global-functional and the situational approaches in U-16 teams. For U-18 teams, there was a choice for the technique and situational approaches, justified by the requirements for players' development. We have analyzed the discourses of female team coaches, and possible differences can be found when analyzing male teams.
Considering that handball players are inserted in a complex and dynamic environment, global-functional, and situational approaches should be given a prominent position (as presented in all stages), especially due to the simultaneous development of technical and tactical aspects. In contrast, the technical approach does not offer a rich environment for the development of players' decision-making ability, but was recognized as a central position in U-18 teams, possibly related to players' specialization, and technical improvement.

Nevertheless, the emphasis on the technical approach does not improve players' decision-making ability by the low transfer to the game context. The diversified environment prioritized in the situational and global-functional approaches provides questions that emerge from interactions between players, being valuable for understanding the game on U-16 and U-18 teams.

We consider that a specialization of players should be conducted gradually, with players experiencing different teaching approaches. This finding was possible after the comparison with other studies that investigated coaches' discourses about teaching in other stages (U-12 and U-14 teams).

Information on teaching choices is particularly interesting due to the implications in the long-term handball training, with practical applications on "how to teach" in each stage. Our findings may also start discussions on the curriculum of the long-term handball training, starting from coaches' discourses.

We analyzed a particular scenario of Brazilian handball, and despite the high representativeness of the coaches, the theme deserves more investigation. Future studies should investigate coaches of other states and of different competitive levels (school, regional or national leagues). 


\section{Endnotes}

${ }^{[1]}$ The "Open Games of state of São Paulo" is a competition in which most of the state teams participate, each representing a different city.

\section{References}

1. Garganta J. O ensino dos jogos desportivos. 3.ed. Porto: Centro de Estudos dos Jogos Desportivos/Universidade do Porto, 1998.

2. Tan CWK, Chow JY, Davids K. 'How does TGfU work?': examining the relationship between learning design in TGfU and a nonlinear pedagogy. Physical Education and Sport Pedagogy. 2012;17(4):331-48.

3. Menezes RP, Marques RFR, Nunomura M. Early sport specialization and the teaching of invasion games (Especialização esportiva precoce e o ensino dos jogos coletivos de invasão). Movimento. 2014;20(1):351-73.

4. Matias CJAdS, Greco PJ. Cognição e ação nos jogos esportivos coletivos. Ciência \& Cognição. 2010;15(1):252-71.

5. Menezes RP, Reis HHBd, Tourinho Filho H. Ensino-aprendizagemtreinamento dos elementos técnico-táticos defensivos individuais do handebol nas categorias infantil, cadete e juvenil (Teachinglearning-training of individual technical-tactical elements of handball for under-14, under-16 and under-18 teams). Movimento. 2015;21(1):261-73.

6. Menezes RP, Marques RFR, Nunomura M. O ensino do handebol na categoria infantil a partir dos discursos de treinadores experientes (Handball teaching in under-14 teams according to experienced coaches' discourses). Movimento. 2015;21(2):463-77.

7. Menezes RP, Marques RFR, Nunomura M. Teaching handball to players under-12: the perspective of Brazilian coaches. Motriz. 2017;23(4):e101792.

8. Côtè J, Baker J, Abernethy B. Practice and play in the development of sport expertise. In: Eklund R, Tenenbaum G, editors. Handbook of sport psychology. Hoboken, Wiley; 2007. p. 184-202.

9. Santos WR, Menezes RP. A especialização esportiva de jogadores de linha e goleiros de handebol na visão de treinadores experientes. Simpósio Internacional de Iniciação Científica da USP; Ribeirão Preto, 2015.

10. Morales JCP, Greco PJ. A influência de diferentes metodologias de ensino-aprendizagem-treinamento no basquetebol sobre o nível de conhecimento tático processual. Rev Bras Ed Fís e Esp. 2007;21(4):291-9.

11. Silva MV, Greco PJ. A influência dos métodos de ensino-aprendizagem-treinamento no desenvolvimento da inteligência e criatividade tática em atletas de futsal. Rev Bras Ed Fís e Esp. 2009;23(3):297-307.

12. Ricci GS, Reis HHBd, Menezes RP, Dechechi CJ, Ferreira CR. Avaliação da aprendizagem do handebol por jovens entre 11 e 14 anos a partir do método situacional. Pensar a Prática. 2011;14(1):1-18.

13. Dietrich K, Dürrwächter G, Schaller HJ. Os grandes jogos: metodologia e prática. Rio de Janeiro, Ao Livro Técnico, 1984.

14. Paula P, Greco P, Souza P. Tática e processos cognitivos subjacentes à tomada de decisão nos jogos esportivos coletivos. In: Garcia E, Lemos K, editors. Temas Atuais V em Educação Física e Esportes. Belo Horizonte, Editora Health; 2000. p. 11-27.
15. Greco PJ. Métodos de ensino-aprendizagem-treinamento nos jogos esportivos coletivos. In: Garcia E, Lemos K, editors. Temas Atuais VI em Educação Física e Esportes. Belo Horizonte, Editora Health; 2001. p. 48-72.

16. Butler JI. Teacher responses to Teaching Games for Understanding. J Phys Ed, Recr and Dance. 1996;67(9):17-20.

17. Light R, Fawns R. Knowing the game: integrating speech and action in games teaching through TGfU. Quest. 2003;55(2):161-76.

18. Menezes RP. Contribuicões da concepcão dos fenomenos complexos para o ensino dos esportes coletivos. Motriz. 2012;18(1):34-41.

19. Holt N, Strean WB, García Bengoechea E. Expanding the Teaching Games for Understanding model: new avenues for future research and practice. J Teach Phys Ed. 2002;21:162-76.

20. Werner P, Thorpe R, Bunker D. Teaching Games for Understanding: evolution of a model. J Phys Educ, Recr and Dance. 1996;67(1):28-33.

21. Galatti LR, Paes RR. Pedagogia do esporte e a aplicação das teorias acerca dos jogos esportivos coletivos em escolas de esportes: o caso de um clube privado de Campinas-SP. Conexões. 2007;5(2):31-44.

22. Galatti LR, Ferreira HB, Silva YPG, Paes RR. Pedagogia do esporte: procedimentos pedagógicos aplicados aos jogos esportivos coletivos. Conexões. $2008 ; 6: 397-408$.

23. Menezes RP, Sousa MSS, Braga JWC. Processo de ensino-aprendizagem-treinamento de handebol para a categoria mirim em instituições não-formais de ensino: concepções e metodologias. Conexões. 2011;9(2):49-69.

24. Greco PJ. Iniciação esportiva universal: metodologia da iniciação esportiva. 1.ed. Belo Horizonte, Editora UFMG, 1998.

25. Paes RR. Educação física escolar: o esporte como conteúdo pedagógico do ensino fundamental. Canoas, Editora Ulbra, 2001.

26. Marconi MA, Lakatos EM. Metodologia científica. 6.ed. São Paulo, Atlas, 2011.

27. Richardson RJ. Pesquisa social: métodos e técnicas. 3.ed. São Paulo, Atlas, 1999.

28. Thomas JR, Nelson JK, Silverman SJ. Métodos de pesquisa em atividade física. 6.ed. Porto Alegre, Artmed, 2012.

29. Menezes RP, Marques RFR, Morato MP. Handball coaches' perception of the offensive and defensive variables of the game in u-12 teams. Motricidade. 2016;12(3):6-19.

30. Boni V, Quaresma SJ. Aprendendo a entrevistar: como fazer entrevistas em Ciências Sociais. Em Tese: Revista Eletrônica dos Pós-Graduandos em Sociologia Política da UFSC. 2005;2(1):68-80.

31. Oliver D, Serovich J, Mason T. Constraints and opportunities with interview transcription: Towards reflection in qualitative research. Social Forces. 2005;84(2):1273-89.

32. Lefèvre F, Lefèvre AMC. Pesquisa de representação social: um enfoque qualiquantitativo. 2.ed. Brasília, Liber Livro Editora, 2012.

33. Lefèvre F, Lefèvre AMC. Discurso do sujeito coletivo: um novo enfoque em pesquisa qualitativa. 1.ed. Caxias do Sul: EDUCS, 2003.

34. Ehret A, Späte D, Schubert R, Roth K. Manual de handebol: treinamento de base para crianças e adolescentes. São Paulo, Phorte Editora, 2002. 
35. Greco PJ, Silva SA, Greco FL. O sistema de formação e treinamento esportivo no handebol brasileiro (SFTE-HB). In: Greco PJ, Fernández Romero JJ, editors. Manual de handebol: da iniciação ao alto nível. São Paulo, Phorte; 2012. p. 235-50.

36. Greco PJ, Benda RN. Iniciação Esportiva Universal: da aprendizagem motora ao treinamento técnico. Belo Horizonte, Ed.UFMG, 1998.

37. Bayer C. O ensino dos desportos colectivos. Lisboa, Dinalivros, 1994.

38. Gréhaigne J-F, Godbout P. Tactical knowledge in team sports from a constructivist and cognitivist perspective. Quest. 1995;47:490-505.

39. Costa ITd, Garganta J, Greco PJ, Mesquita I, Muller E. Relação entre a dimensão do campo de jogo e os comportamentos táticos do jogador de futebol (Relationship between pitch size and tactical behavior of soccer player). Rev Bras EF e Esporte. 2011;25(1):79-96.

40. Memmert D, Almond L, Bunker D, Butler J, Fasold F, Griffin L, et al. Top 10 Research Questions Related to Teaching Games for Understanding. Res Quar Exer Spo. 2015;86(4):347-59.

41. Antón García JL. Balonmano: fundamentos y etapas de aprendizaje. Madrid, Gymnos Editorial, 1990.

\section{Acknowledgments}

Grant \#2013/05854-8, São Paulo Research Foundation (FAPESP)

\section{Corresponding author}

Rafael Pombo Menezes, PhD

University of Sao Paulo, USP, School of Physical Education and Sport of Ribeirao Preto

Ave Bandeirantes, 3900 - Campus USP, 14040-907, Ribeirao PretoSP, Brazil

Email: rafaelpombo@usp.br

Manuscript received on March 12, 2018

Manuscript accepted on July 23, 2018

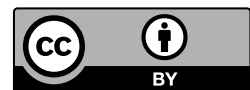

Motriz. The Journal of Physical Education. UNESP. Rio Claro, SP, Brazil - eISSN: 1980-6574 - under a license Creative Commons - Version 3.0 